\title{
Process Improvement on Domestic Wastewater Treatment Stabilization Ponds by Using Mathematical Optimization Approach
}

\author{
${ }^{1}$ Sunarsih*, ${ }^{2}$ Dwi Purwantoro Sasongko and ${ }^{3}$ Sutrisno \\ ${ }^{1,2}$ Department of Mathematics, Faculty of Science and Mathematics \\ Universitas Diponegoro Jalan Prof. Soedarto, SH., Semarang, Indonesia \\ ${ }^{3}$ Department of Physics, Faculty of Science and Mathematics \\ Universitas Diponegoro Jalan Prof. Soedarto, SH., Semarang, Indonesia \\ ${ }^{*}$ Corresponding author: ${ }^{1}$ narsih_pdil@yahoo.com
}

Article history

Received: 14 February 2019

Received in revised form: 14 February 2019

Accepted: 28 April 2019

Published online: 1 August 2019

\begin{abstract}
In this paper, a mathematical optimization approach is used to improve the pollutant degradation process on domestic wastewater treatment stabilization ponds. The optimized process in this research is the pumping process that was modelled as a mathematical optimization problem. By using data that was collected in Sewon wastewater treatment in Yogyakarta, Indonesia, the pumping process can be optimized and the optimal decision was determined that can be applied to operate this wastewater treatment pond.
\end{abstract}

Keywords Domestic wastewater treatment; optimization; pollutant transport

Mathematics Subject Classification 90C20, 90C90, 62P12

\section{Introduction}

Wastewater treatment plants have been used in many countries to reduce the pollutant in the wastewater. Commonly, this treatment plants consisting of several ponds that were used to reduce the pollutant by using the natural processes by taking advantage from the bacteria, algae and zooplankton to reduce the organic pollutant [1]. The main ponds in the wastewater treatment plant are stabilization pond or facultative pond and maturation pond. The main purpose of this wastewater stabilization pond is to store and then to process the wastewater with some desired retention time [2]. Some mathematical models have been developed as an approach to analyze, observe and optimize the performance of the wastewater stabilization pond. For example, a linear optimization mathematical model was developed to optimize the performance of facultative pond [3]. Other approaches were performed, for example by simulating the effectiveness and purification efficiencies of the BOD [4], optimization model by minimizing the cost construction [5] by using natural adsorbent [6] and their extensions like sewage treatment in extreme area [7], analysis of nitrogen in waste stabilization ponds in the removal mechanism point of view [8] and maturation pond optimization [9]. 
Advanced researches were also conducted in order to maintain the ponds better, for example in [10] the advanced statistical analysis was applied to optimize the stabilization pond, in [11] an optimization model was governed to reduce the feed in the distillation column of the pond, in [12] it was considered the variables influence the phosphorus content in a waste stabilization pond, in [13] it was considered an integrated model of hydraulic, physico-chemical and micro-biological processes, in [14] it was considered the combination model of oxygen electrode and biological model, in [15] the Indicator Organism and Organic Matter was optimized by a mathematical optimization model proposed in the research. The more advanced researches were conducted to take advantage of the material residue in wastewater pond as to produce Soil-Cement Bricks [16] and reuse of the water from the pond [17]

In this paper, we develop a model to optimize the pollutant reducing process on facultative stabilization pond in Sewon Bantul wastewater treatment plant. The model is developed to determine the optimal volume of the wastewater that will be processed on the facultative stabilization pond and to determine how long the storing time of the wastewater so that the efficiency value of the pond will near as close as possible to the efficiency reference value.

\section{Methodology}

The methodology used in this research is explained as follows. First, we employ the assumptions hold by the model approach which are (1) all units of wastewater volume in a day is the average of the observed data (2) we calculate the efficiency percentage of a pond by value of BOD degradation rate times the storing time day divided by itself plus one (3) the standard of the wastewater quality is different from one region/country to the others, then in this research we apply the quality standard that decided by the local government (Yogyakarta Province). In the next step, we identify and define all parameters/variables in which influence the pond in the model. We decide to include the wastewater load in inlet, inflow rate in the inlet and stabilization pond, wastewater volume prior to the pond, wastewater volume processed in the pond, concentration of BOD in the pond, sum of all wastewater volume in four observed ponds, efficiency value at each pond, and quality standard value of the wastewater.

Formulation of the mathematical optimization model is the next crucial step. In order to gain the best overall performance of the wastewater treatment, we decide to maximize the total wastewater volume in all ponds, and furthermore we decide to minimize the squared difference between the treatment efficiency value at each pond to a reference value decided by the decision maker in the wastewater plant. This means that the decision maker or manager wants to bring the treatment efficiency value to some value referred by himself. By combining these two objectives we formulate the objective function of the model as minimizing the total wastewater load minus total squared difference of efficiency value. The constraints that should be hold are that the quality standard requirement and wastewater volume processed in the ponds. The observed data from Sewon Bantul Yogyakarta wastewater treatment ponds, then we substituted it into the formulated model. Finally, by using quadratic optimization solver in LINGO 17.0 software, we solve the optimization problem to obtain the optimal decisions which are discovering how much of the wastewater volume that should be processed in the pond and how much the corresponding treatment efficiency value that will be achieved. 


\section{Mathematical Model}

The formulated model is covering the facultative ponds only and it does not include the maturation pond that illustrated in Figure 1.

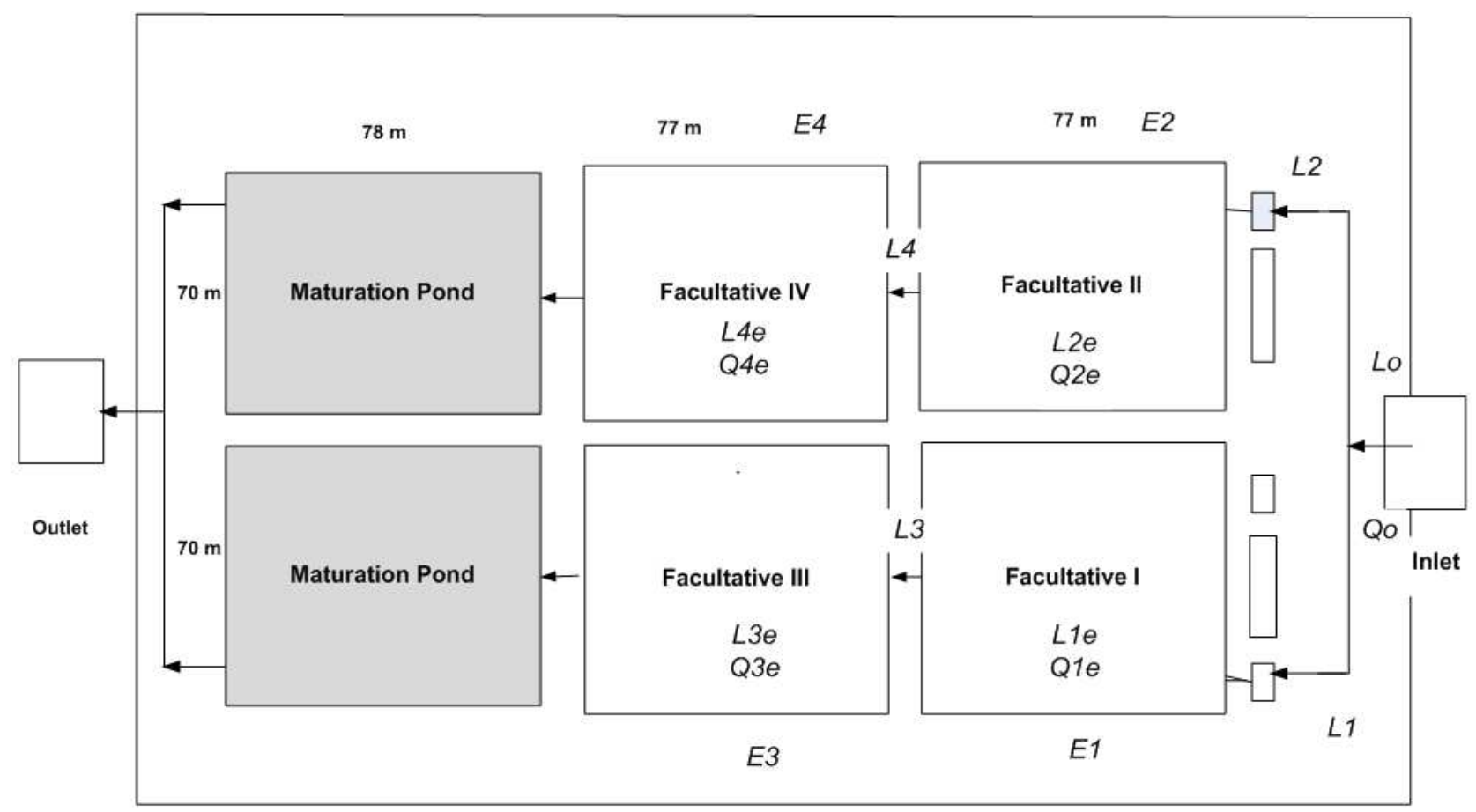

Figure 1: Sewon Bantul Wastewater Treatment Plant

The processing of the wastewater is started in inlet and divided into four facultative stabilization ponds. The model was formulated as a quadratic optimization problem where the variables and the parameters are:

$L_{0}$ - Initial wastewater load volume in inlet $(\mathrm{kg} /$ day)

$Q_{0}$ - Wastewater inflow rate in the inlet $\left(\mathrm{m}^{3} /\right.$ day $)$

$Q_{e}^{p}$ - Wastewater inflow rate in facultative pond $p\left(\mathrm{~m}^{3} /\right.$ day $)$

$L_{p}$ - Wastewater load volume prior to pond $p(\mathrm{~kg} /$ day $)$

$L_{e}^{p}$ - Wastewater volume processed in pond $p(\mathrm{~kg} /$ day $)$

$C_{p}$ - Concentration of Biological Oxygen Demand at pond $p(\mathrm{mg} / \mathrm{L})$

$L$ - Wastewater load for all ponds (kg/day)

$E_{p}$ - Efficiency value of the treatment at pond $p$ (in percentage)

$E_{p}^{r}$ - Efficiency reference value of the treatment at pond $p$ (in percentage) decided by director or DM

$B M$ - Quality standards of wastewater decided by the local government 
The objective function that will be optimized has two components. The first objective is the total volume of the processed wastewater in all ponds that should be maximized. The second objective is the total squared value of the difference between treatment efficiency value and the reference efficiency value for all ponds that should be minimized. This reference efficiency value will be determined by the decision maker which means that the decision maker wants to bring the wastewater process efficiency value to the given reference as close as possible. Hence, the model was formulated as follows:

$$
\max Z=\sum_{p=1}^{P} L_{p}^{e}-\sum_{p=1}^{P}\left(E_{p}-E_{p}^{r}\right)^{2}
$$

subject to:

$$
\begin{gathered}
E_{p} C_{p} \leq B M, \forall p \in P \\
L_{p}^{e} \leq L_{p}, \forall p \in P
\end{gathered}
$$

The value of $L_{p}^{e}$ is formulated as $L_{p}^{e}=\frac{\left(Q_{p}^{e} \cdot C_{p}\right)}{1000}$ or $C_{p}=\frac{\left(1000 L_{p}\right)}{Q_{p}^{e}}$ which means that the volume of the input wastewater on these facultative ponds is the flow rate of the wastewater including the organic matter i.e. Biochemical Oxygen Demand (BOD). The efficiency of each facultative pond is calculated by using the following formula:

$$
E_{p}=\frac{k . t}{1+k . t}
$$

where $k$ is the BOD degradation rate and $t$ is the storing time (in day) of the wastewater in the pond. Hence, the mathematical model can be rewritten as follows:

$$
\max Z=\sum_{p=1}^{P} L_{p}^{e}-\sum_{p=1}^{P}\left(E_{p}-E_{p}^{r}\right)^{2}
$$

subject to:

$$
\begin{aligned}
E_{p} \frac{\left(1000 L_{p}\right)}{Q_{p}^{e}} & \leq B M, \forall p=1,2,3,4 ; \\
& L_{1}^{e} \leq L_{1} \\
& L_{3}^{e} \leq L_{1}-L_{1}^{e} ; \\
& L_{2}^{e} \leq L_{2} \\
& L_{4}^{e} \leq L_{2}-L_{2}^{e} .
\end{aligned}
$$

\section{Results and Discussions}

The observation data to evaluate model were taken in Sewon WWTP located in Bantul district, Yogyakarta Province, Indonesia. Data value for some parameters were used in our previous works [3]. The inflow rate of the wastewater $\left(Q_{0}\right)$ is assumed to be the average of the inflow rate for one year which is $11,238.38 \mathrm{~m}^{3}$ /day and the wastewater processing time in the facultative 
ponds is 4.83 day on average. The wastewater load volume in facultative pond I and II are a half of the inflow load which is $L_{0}=4,799.6 \mathrm{~kg}$ /day and the BOD for $L_{1}$ and $L_{2}$ is the half which is $2,399.8 \mathrm{~kg} /$ day. The wastewater quality standards that we used is $50 \mathrm{mg} / \mathrm{L}$ as the local governments' policy [18]. The optimization problem (5) was solved in LINGO 17.0 by using daily used personal computer with Windows 10 x64 of operating system, Dual Core 3.0 $\mathrm{GHz}$ of processor and $4 \mathrm{~GB}$ of memory. Based on the data collected in the inlet, the BOD concentration is $68.3 \mathrm{mg} / \mathrm{L}-177.2 \mathrm{mg} / \mathrm{Landin}$ outlet is $13 \mathrm{mg} / \mathrm{L}-18,8 \mathrm{mg} / \mathrm{L}$ and the used BOD degradation coefficient is 1.1 [3].

Table 1: Optimization Result

\begin{tabular}{|c|c|c|c|c|c|c|c|}
\hline Pond $(p)$ & $L_{e}^{p}$ & $E_{p}$ & $E_{p}^{r}$ & $Q_{p}^{e}$ & $L_{p}$ & $k(\mathrm{p})$ & $t(\mathrm{p})$ \\
\hline 1 & 1199.5 & 0.280846 & 0.5 & 13475 & 2399 & 1.1 & 0.355018 \\
2 & 1199.5 & 0.280846 & 0.5 & 13475 & 2399 & 1.1 & 0.355021 \\
3 & 1199.5 & 0.561692 & 0.9 & 13475 & 1199.5 & 1.1 & 1.165002 \\
4 & 1199.5 & 0.561692 & 0.9 & 13475 & 1199.5 & 1.1 & 1.165002 \\
\hline
\end{tabular}

From the optimization results given in Table 1, it can be concluded that the optimal wastewater volume in each pond should be $1199.5 \mathrm{~kg}$ per day where the treatment efficiency of the pond I and II is $28 \%$ and the treatment efficiency value of pond III and IV is $0.56 \%$. The corresponding storing time in pond I and II is 0.35 day and in pond III and IV is 1.16 day.

\section{Conclusions}

In this paper, a mathematical model in a quadratic optimization form was considered which was used to optimize the wastewater processing in Sewon wastewater treatment plant. The results was shown that the optimal wastewater volume of each pond should be $1199.5 \mathrm{~kg} /$ day and the storing time at pond I and II is 0.35 day which had 0.28 of the treatment efficiency and the storing time at pond III and IV is 1.16 day which had 0.56 of the treatment efficiency.

In the future works, we will develop the model so that it can be used to optimize the wastewater processing including the maturation pond. Furthermore, there will be more data collected to verify and determine the parameter value via parameter estimation of the model so that the accuracy of the model will be more clarified.

\section{References}

[1] Sunarsih, S., Purwanto, P. and Budi, W. S. Mathematical modeling regime steady state for domestic Wastewater Treatment facultative stabilization ponds. J. Urban Environ. Eng. 2013. 7(2): 293-301.

[2] K Naddafi et al. Performance evaluation of wastewater stabilization ponds in Arak-Iran. Iranian J. Environ. Health Sci. Eng. 2009. 6(1): 41-46.

[3] Sunarsih, Widowati, Kartono and Sutrisno. Mathematical Analysis for the Optimization of Wastewater Treatment Systems in Facultative Pond Indicator Organic Matter. E3S Web Conf. 31(05008): 1-3. 
[4] Kogo, B. K., Biamah, E. K. and Langat, P. K. Optimized Design of a Hybrid Biological Sewage Treatment System for Domestic Wastewater Supply. J. Geosci. Environ. Prot. 2017. 05(05): 14-29.

[5] Olukanni,D. O. and Ducoste, J. J. Optimization of waste stabilization pond design for developing nations using computational fluid dynamics. Ecol. Eng. 37(11): 1878-1888.

[6] Gopakumar, A., Narayan, R., Nagath, S.A., N.P., Mohammed, R. S. and Chandran, S. Waste Water Treatment Using Economically Viable Natural Adsorbent Materials. Mater. Today Proc. 5(9): 17699-17703.

[7] Recio-Garrido, D., Kleiner, Y., Colombo, A. and Tartakovsky, B. Dynamic model of a municipal wastewater stabilization pond in the arctic. Water Res. 2018. 144(1): 444-453.

[8] Mayo, A. W. and Abbas, M. Removal mechanisms of nitrogen in waste stabilization ponds. Phys. Chem. Earth 2014. 72(1): 77-82.

[9] Cortés Martínez, F., Treviño Cansino, A. , Sáenz López, A., González Barrios, J. L. and De La Cruz Acosta, F. J. Mathematical modeling and optimization in the design of a maturation pond. J. Appl. Res. Technol. 2016. 14(2): 93-100.

[10] Halters, F., Zondervan, E. and De Haan, A. Integrated optimization of a waste water treatment plant using statistical analysis. J. Hazard. Mater. 2010. 179(1-3): 480-487.

[11] Ferella, F. Journal of Environmental Chemical Engineering Optimization of a plant for treatment of industrial waste solutions?: Experimental and process analysis. J. Environ. Chem. Eng. 2018. 6(1): 377-385.

[12] Sells, M. D., Brown, N. and Shilton, A. N. Determining variables that influence the phosphorus content of waste stabilization pond algae. Water Res. 2018. 132(1): 301-308.

[13] Ho, L. T., Alvarado, A., Larriva, J., Pompeu, C. and Goethals, P. An integrated mechanistic modeling of a facultative pond: Parameter estimation and uncertainty analysis. Water Res. 2019. 151(1): 170-182.

[14] Novak, M. and Horvat, P. Mathematical modelling and optimisation of a waste water treatment plant by combined oxygen electrode and biological waste water treatment model. Water Res. 2012. 36(1): 3813-3825.

[15] Martínez, F. C., Cansino, A. T., Aracelia, M., García, A., Kalashnikov, V. and Rojas R. L. Mathematical Analysis for the Optimization of a Design in a Facultative Pond?: Indicator Organism and Organic Matter. Mathematical Problems in Engineering. 2014. 2014(1): 1-12.

[16] Rodrigues, L. P., Nilson J. and Holanda F. Recycling of Water Treatment Plant Waste for Production of Soil- Cement Bricks. Procedia Mater. Sci. 8(1): 197-202.

[17] Raghuvanshi, S., Bhakar, V., Sowmya, C. and Sangwan, K. S. Waste water treatment plant life cycle assessment?: treatment process to reuse of water. Procedia CIRP. 2017. 61(1): 761-766.

[18] Gubernur DI Yogyakarta (Governor of Special Region Yogyakarta). Surat Keputusan Gubernur Kepala Daerah Istimewa Yogyakarta (Decree of Special Region Yogyakarta Governor). No. 214/KPTS/1991. 1991. 